\title{
Arctic Message Arctic Messenger: A Review and Commentary
}

David P. Stone. The Changing Arctic Environment: The Arctic Messenger (Cambridge University Press. New York. 2015). 360 pages, hardcover. ISBN 9781107094413.

Sheila Watt-Cloutier. The Right to Be Cold (Allen Lane. Toronto. 2015). 336 pages, hardcover. ISBN 9780143190226.

What does the future hold for the circumpolar Arctic? Well-known American academic Lawrence C. Smith foresees mass migration of people to the region - cities on the tundra? - in the coming decades as the planet warms. Writing in the New York Times, Scott Borgerson, formerly with the US Coastguard, foresees Arctic shipping between Asia, Europe, and North America in a seasonally ice-free Arctic Ocean, and "anarchy" as countries compete for the final frontier's energy and mineral resources. Just when all of this may come about is unclear, but there is a lot at stake. The US Geological Survey estimates that 90 billion barrels of oil, almost 1,700 trillion cubic feet of natural gas, and 44 billion barrels of natural gas liquids are yet to be discovered in the region, primarily in the seas that fringe the Arctic Ocean.

Particularly indicative of the region's incorporation into the "world system" by climate change and globalization is the recent admission of China, India, Japan, South Korea, and Singapore as official observers to the eight-nation Arctic Council, the region's premier international cooperative body. These Asian states and the six European states already involved in the Council are staking out their place in the future Arctic sun.

But there is another side to the circumpolar Arctic in addition to its energy, minerals, intercontinental shipping potential, and rising geopolitical importance. In 2002, the Governing Council of the United Nations Environment Programme adopted unanimously a resolution that characterizes the Arctic as the world's barometer of environmental change. Also, the region is home to Indigenous peoples-Inuit, Athabaskans, Gwich'in, Sami, and more-who have been there for millennia. All who want to know more about these elements of the Arctic should read the well-written, superbly edited, and the hugely informative books by David P. Stone and Sheila Watt-Cloutier, and they should do so in the given order.

Stone deals primarily with the science-what we know. Watt-Cloutier deals primarily with public policy — what we should do as a result of what we know. Here are voices of knowledge, experience, and wisdom. Stone and Watt-Cloutier know and 
respect each other. Each cites the other which explains why their shared take home message is, in Watt-Cloutier's words, "save the Arctic and save the planet." It sounds a little trite and clichéd, but is nevertheless a badly needed message of hope as well as a call for action.

Originally from England, Stone took a PhD in Oceanography at the University of British Columbia in Canada and was employed by the Government of Canada for many years on Arctic issues. From 1993 to 1998, he chaired the circumpolar Arctic Monitoring and Assessment Programme (AMAP) set up in 1991 when glasnost (openness) and perestroika (restructuring) were in full swing. In many respects, his book is the story of assessments conducted by AMAP, based in Oslo, but more than this, he shows how scientific knowledge of the region has advanced in the past 30 years and how governments have often hesitatingly responded.

Happily, The Changing Arctic Environment uses no "twelve cylinder words" as the late John Bayly, a well-known Canadian lawyer, referred to technical writing. This book is written for the public and opinion makers who influence the development and implementation of public policy. Chapters address radioactivity, acidification and Arctic haze, ozone depletion, persistent organic pollutants (including pesticides and insecticides), mercury, and climate change. At the end of each chapter is an often engaging summary - The Long and the Short of It - to reinforce earlier conclusions. There is an autobiographical tinge to this book, and Stone gives the nod to his many colleagues and collaborators including Lars-Otto Reiersen and Simon Wilson of AMAP, and his spouse Thérèse.

In environmental terms, the Arctic is very much part of the wider world. Arctic haze caused by emissions of sulfur and nitrogen oxides from mid-latitude industrial processes was reported by Inuit and explorers in the 19th century. In recent decades, emissions in tropical and temperate countries of persistent organic pollutants (POPS) including DDT (used as an insecticide) and PCB (used as a coolant in electrical apparatus) have been traced to the Arctic where they bioaccumulate and biomagnify in the food web. As a result of consuming marine mammals, many Canadian Inuit women in the late 1980s were found to have elevated levels of these POPs in their blood and fatty tissues. Many of these contaminants pass through the placenta, raising very real concerns about the health of infants as well as their parents. This was quite a surprise to scientists, and it vividly illustrates the truth of Watt-Cloutier's epigram, "we are all connected."

Stone is puzzled and dismayed by the behavior of some politicians who act contrary to the scientific consensus on climate change. This is not a finger pointing book, but in asking why some politicians act contrary to science, he invites the reader to dip into Merchants of Doubt by Oreskes and Conway. Based in the United States, these historians document the unsavory tactics of some corporations aided by some scientists to prevent the adoption of public policies to address acid rain, the ozone hole over Antarctica, and climate change, claiming that the scientific jury is still out on the cause of these environmental problems.

Stone's reading of the Arctic barometer is that there is rough weather ahead, but The Changing Arctic Environment is not all doom and gloom. International conventions 
which draw upon the work of AMAP to reduce emissions of POPs, mercury, Arctic haze, acid rain, radionuclides, and other substances are having a measurable and positive impact, although progress is slow. Worryingly, new substances that threaten public health are being found in the Arctic illustrating the need not only for vigilance and expanded monitoring but also broadening of international agreements.

The Changing Arctic Environment ends with two poignant chapters, "Has the Arctic Messenger Been Noticed?" and "Keeping the Rovaniemi Flame Alive," a reference to the small town in northern Finland where AMAP and the broader Arctic Environmental Protection Strategy of which it was a part, were announced in 1991. Stone feels keenly about AMAP and at times describes it in very human terms as his "mentor." Here is an author trying to shift public perceptions and government policy using a region that he knows can tell us much about what we are doing to the Earth.

Stone ends with a challenge and a proposal to the Arctic Council which in 1996 subsumed the Arctic Environmental Protection Strategy. The UN Framework Convention on Climate Change has failed to persuade countries to reduce their emissions of greenhouse gases, but the Arctic barometer says we must act. So what to do? He urges a regional agreement among the Arctic states not only to protect the region but also to lead (and shame?) the world into global action.

Good science in and by itself does not guarantee good public policy. Institutions, particularly government agencies, are often slow moving, risk adverse, and are perennially behind the times. This situation is not helped by the poor communication skills of scientists who are more at ease in the lab or in the field rather than before parliamentary committees or briefing ministers, and the inability of many politicians to understand the language of science. In this daunting context, there are sometimes individuals - rare, creative, and, out of necessity, courageous - who are important in turning science into public policy. Watt-Cloutier is one of them.

If The Changing Arctic Environment has a hint of autobiography, The Right to Be Cold is the real thing. This is an uplifting story of an Inuk woman born in Kuujjuaq, Nunavik (northern Québec), in very humble circumstances, who took the Arctic Message to the world, gaining global recognition and a nomination for the 2007 Nobel Peace prize that she came within an ace of winning.

There is a curious sense of inevitability about this story, for Watt-Cloutier seems to have been destined very early for big things in life. Raised without a father or grandfather and mindful of the fact that her biological father was "White" and that she did not look like an Inuk, her early years were spent living on the land, travelling by dog teams. As a 10-year-old, she was thought to be "promising" and shipped off to school in Nova Scotia, and as a teenager attended the residential school in Churchill. Supposed to churn out carpenters, mechanics, and artisans, instead, a whole generation of future Inuit politicians graduated from Churchill to lead the cause of land claims and self-government exemplified by the 1993 Nunavut Land Claims Agreement and the 1999 creation of the Nunavut Territory.

In her lifetime, Inuit moved from a semi-nomadic existence to settled communities, and suffered social traumas and cultural breakdown as a result. She was no exception. Yet, she came through it all, even strutting her stuff in white Go Go boots 
at residential school accompanying The Harpoons, an aptly named Inuit rock and roll group - an unforgettable image. It was, after all, the time of mini skirts and the Beatles.

Watt-Cloutier draws strength from her forebears and culture. She explains that the hunting way of life remains important for it teaches individuals to show patience, to endure, to have courage and self-confidence, to cooperate, and to base decisions on evidence. Only hunters who understand their natural environment survive. These values informed her political activities on POPs and climate change as President of the Canadian branch of the Inuit Circumpolar Council, and from 2002 to 2006 as its International Chair.

Informed by AMAP that POPs were a threat to the health and welfare of her people, Watt-Cloutier was determined to do something about it. On behalf of a coalition of Arctic Indigenous peoples, she attended negotiations in Montreal, Nairobi, Bonn, Geneva, Johannesburg, and Stockholm where she spoke unhesitatingly and with skill about the health and cultural impacts of POPs.

At the opening session in Montreal, she received a round of applause from the delegates, something that just does not happen in the measured realm of interstate negotiations; a sign of her quickly established and widely acknowledged moral authority and legitimacy. At negotiations in Nairobi, she presented Klaus Topfer, Chair of UNEP and Germany's former Minister of the Environment, with a carving of an Inuit mother and child. Visibly moved, Topfer gave an unscripted speech to the delegates characterizing Inuit as the "conscience" of negotiations.

Committed to a global ban of DDT but recognizing its use in fighting malaria in tropical countries, Watt-Cloutier said in Johannesburg that Inuit would not be party to an agreement that threatened the health of others. Hers was the intergenerational and cross-cultural perspective of mothers and grandmothers. As a result, the third preambular paragraph of the 2001 Stockholm Convention on POPs singles out the Arctic and its Indigenous peoples and characterizes POPs as a health and cultural issue, a practice continued in the 2013 Minamata Convention on mercury.

Watt-Cloutier is best known for her work on climate change. In the dying days of the Clinton presidency, and when it was chair of the Arctic Council, the United States proposed that the AMAP lead an assessment of the impacts of climate change in the Arctic. Drawing on her experience with POPs, Watt-Cloutier politely insisted at the Council's October 2000 ministerial meeting that it consider health and culture, issues not addressed in global assessments conducted by the Intergovernmental Panel on Climate Change, and make policy recommendations.

Carried out by more than 300 scientists from 15 countries, early drafts of this assessment drew a very worrying picture of the impacts of climate change in the North. The hunting culture of Inuit and other Arctic Indigenous peoples was to be severely threatened. All of this was unwelcome news to deniers of climate change in the George W. Bush White House, and in 2003 the State Department sought to renege on the commitment to policy recommendations. In response, Watt-Cloutier went to Washington DC., almost a reprise of Jimmy Stewart's Mr. Smith Goes to Washington, the famous 1939 film. 


\section{T. Fenge}

In front of perhaps 400 people packed into the hearing room, in September 2003, she spoke to the Senate Committee on Commerce, Science, and Transportation chaired by Senator John McCain. A frisson of indignation swept the audience when she spoke of the State Department's attempt to abandon the commitment to policy recommendations. In the following days, this revelation was front page copy in The New York Times and The Washington Post, and the story reverberated around the world.

The United States backed off. When the Arctic Climate Impact Assessment was approved by Arctic Council ministers the following year, it included approved policy recommendations that focused on the need to reduce emissions of greenhouse gases. Targets and timetables were missing, but in its day, this assessment and the accompanying policy recommendations were seen as something of a breakthrough. Watt-Cloutier's moral authority and legitimacy had trumped political expediency. The Arctic Message was being turned into public policy as a result of the work of the Arctic Messenger. In the process, the Arctic and its people and wildlife had replaced collapsing ice shelves in Antarctica as the iconic global images of climate change.

At the December 2005 Conference of Parties to the UN Framework Convention on Climate Change, Watt-Cloutier announced a petition to the Inter-American Commission on Human Rights on behalf of herself and more than 60 named Inuit in northern Canada and Alaska. She alleged that the environmental, social, and cultural impacts of climate change in the Arctic was the result of virtually unrestricted emissions of greenhouse gases by the United States in contravention of the individual and collective human rights of Inuit guaranteed in the 1948 American Declaration on the Rights and Duties of Man.

The petition was a hard sell. It prompted a hearing in Washington DC on the connection between human rights and climate change, the first time globally that a quasi-judicial human rights tribunal had examined climate change. Inuit did not, however, get the relief they sought - a commitment by the United States to reduce its emissions and to work with Inuit to adapt to the unavoidable impacts of climate change. Be that as it may, within a few years, human rights concerns were "mainstream" at annual meetings of the global climate change convention.

There is a sense of relief and personal freedom at the end of The Right to Be Cold that Watt-Cloutier is no longer under pressure to trim her sails to the imperatives and foibles of institutions. She comes full circle, back to the core, land-based values of the culture in which she is so obviously well grounded.

Terry Fenge

Terry Fenge is a consultant with many years of experience in Arctic environmental and Aboriginal issues. From 1996 to 2006, he was Strategic Counsel to Sheila Watt-Cloutier, Chair of the Inuit Circumpolar Council, and in this capacity often interacted with David P. Stone. 